\title{
The Voice of Geber (Lam 3) in the Panorama of Speaking Voices in the Book of Lamentations
}

\author{
CEZARY KORZEC \\ University of Szczecin \\ cezary.korzec@usz.edu.pl \\ ORCID: 0000-0002-8719-2927
}

\begin{abstract}
The present study, acknowledging the centrality of Lam 3 in the book of Lamentations, examines the development of the speaking voice of the geber in this chapter and compares it with other voices speaking in the book. The questioned identity of the geber becomes a model for other 'voices': the narrator and the Daughter of Zion. The destruction of the city, carried out by God himself, indicates an exhaustion of the old institutions and the need for a new identity of both the Daughter of Zion and the supporters of the community of the city (i.e., the narrator) in the days of crisis.
\end{abstract}

KEYWORDS: Lamentations, geber, speaking voices

$\mathrm{n}$ the studies of Lamentations 3 much attention has been given to the figure of haggeber (TM), aner (LXX), vir (Wlg), or the man (RSV, NLV, ASV, etc.), ${ }^{1}$ present from the very first verse of this chapter. Many commentaries deal with it in separate excursuses or in extensive notes, where several intense scholarly debates concerning various philological, historical, poetic and theological aspects of this figure are outlined. ${ }^{2}$ Neither of these debates has reached any certain conclusion and new contributions, arising from the application of new methodologies, continue to be added. The most significant recent publications include commentaries

1 Translator's note: Unless indicated otherwise, quotations from the biblical texts follow the New Revised Standard Version Catholic Edition, with the following consistent modifications: the word 'man' has been added where appropriate, to express the Hebrew word 'geber,' central to the argument presented in this study; the expression 'the Lord' has been replaced with the divine name YHWH; the expressions 'Daughter of Zion' and 'Daughter of Edom' have been capitalized.

2 For a good example of such an excursus, see K. Koenen, Klagelieder (Threni) (ZBK.AT 20; Neukirchen-Vluyn: Neukirchere Verlaggesellschaft 2015) 214-221. Notes and longer comments dedicated to this figure can be found in A. Berlin, Lamentations. A Commentary (Louisville, KY: Westminster John Knox 2002) 84f; E.M. Obara, Lamentazioni. Introduzione, traduzione e commento (Cinisello Balsamo: San Paolo 2012) 86f; M.J. Bier, 'Perhaps there is Hope.' Reading Lamentations as a Polyphony of Pain, Penitence, and Protest (London: Bloomsbury 2015) 105-109. See also the following articles: M. Saebø, "Who is 'the Man' in Lamentations 3? A Fresh Approach to the Interpretation of the Book of Lamentations," Understanding Poets and Prophets. Essays in Honour of George Wishart Anderson (ed. A.G. Auld) (JSOTSup 152; Sheffield: JSOT 1993) 294-306; C. Korzec, "I-the Strong Man in the Face of His Wrath (cf. Lam 3:1). A Man in Face of Divine Violence," Bible Caught in Violence (ed. C. Korzec) (New York - Berlin - London: Lang 2019) 75-89. 
written from the feminist perspective Adele Berlin, Kathleen M. O'Connor, Carleen Mandolfo and Elżbieta M. Obara ${ }^{3}$ emphasise the role of the female figures, such as widow, mother, daughter, and bride, and consider the violence described by the author of Lamentations by means of numerous metaphors and images. This added further emphasis to the conspicuous male figure speaking in Lam 3.

The significance of images and metaphors originating from a certain number of different semantic fields, such as warfare, hunting, urban life, and worship, is well known in the book of Lamentations. As a result of the renewed interest in this imagery, new questions regarding the book's literary devices arose, leading to a revival of literary studies of this biblical text. Accordingly, scholars's attentions shifted from the question of genre back to deepened studies of stylistic devices used in Lamentations. Against this background William F. Lanahan ${ }^{4}$ pointed out different voices speaking in the five poems of which the book consists. ${ }^{5}$

The achievements of the scholars who recognised the female figures and the images of violence in Lamentations and acknowledged the presence of different 'voices' speaking in this biblical book not only broadened our knowledge about each of the issues in itself but also influenced our understanding of other aspects of Lam, including the figure of geber. Moreover, they strengthened the conviction about the book's unity and about a network of literary connections between its clearly delineated parts. The latter issue is expressed, as it has been mentioned above, in the generally accepted view that there are five poems included in Lam

3 See Berlin, Lamentations; K.H. O'Connor, Lamentations and the Tears of the World (Maryknoll, NY: Orbis Books 2002); C. Mandolfo, Daughter Zion Talks Back to the Prophets. A Dialogic Theology of the Book of Lamentations (Atlanta, GA: Society of Biblical Literature 2007) and Obara, Lamentazioni. For a brief discussion of the contribution made by feminist studies in the field of Lam exegesis, see H.A. Thomas, Feminist Interpretation(s) And Lamentations, Great Is Thy Faithfulness? Reading Lamentations as Sacred Scripture (eds. R.A. Parry - H.A. Thomas) (Eugene, OR: Pickwick 2011) $166-174$.

$4 \quad$ See W. Lanahan, "The Speaking Voice in the Book of Lamentations," JBL 93 (1974) 41-49.

5 This problem has accumulated a considerable amount of literature. Scholars differ in their opinions regarding the identification of various speaking 'voices' and the locations of their utterances in the book. Apart from separate chapters dedicated to this issue in a number of commentaries, see especially the following book-length studies: C.W. Miller, Poetry and Personae. The Use and Functions of the Changing Speaking Voices in the Book of Lamentations (Diss. University of Denver; Denver, CO 1996), K.M. Heim, "The Personification of Jerusalem and the Drama of Her Bereavement in Lamentations," Zion, City of our God (eds. R.S. Hess - G.J. Wenham) (Grand Rapids, MI: Eerdmans 1999) 129-170; T. Linafelt, Surviving Lamentations. Catastrophe, Lament, and Protest in the Afterlife of a Biblical Book (Chicago, IL: University of Chicago Press 2000) 35-43, C.W. Miller, "Reading Voices: Personification, Dialogism, and the Reader of Lamentations 1," BibInt 9/4 (2001) 393-408; K.P. Soltau, A Structural Analysis of the Book Lamentations (Diss. Bob Jones University; Greenville, SC 2003) 53-139, and the article Sh. Kang - P.M. Venter, "A Canonical-Literary Reading Of Lamentations 5," HTS 65/1(2009) 1-7, DOI:10.4102/htsv65i1.278. For a comprehensive critical review of research on this aspect of the discussed biblical book, including the contributions of William F. Lanahan, Elisabeth Boase, Iain Provan and Erhard Gerstenberger and other researchers, see Koenen, Klagelieder, 59*-64*. 
and that each of them is a coherent literary unit. ${ }^{6}$ In spite of that, the poems should not be treated as separate; there are numerous connections between them. ${ }^{7}$

The present study is a literary analysis of Lamentations, in which the unity of the book is acknowledged. The figure of geber in the third poem, as well as its relation to other voices speaking in other poems of the book are reconsidered from this perspective. The main methodological tool applied in this study is the analysis of style and composition.

\section{The geber in Lam 3}

\subsection{The geber as the Speaking Voice}

The character of geber in Lam 3 is strongly connected with the presence of the literary device mentioned above. It is one of the distinguishing features of Lam, easy to notice from the first reading. The geber as a voice is one of the characters in the book, ${ }^{8}$ who all reveal themselves known through speaking. Like other voices, he is identified through the content of his utterances. We should also consider the fact that the text of Lam gives no other indication regarding the identity of the geber-man, or the identities of any of the other voices. The voices are distinguished from one another according to the following criteria:

- gender: male and female 'voices'

- different geographical and chronological conditions: inhabitants of the besieged city and external observers

- number: the individual voice and the collective voice of the community

- variety of experiences and the resulting perspectives from which the tragic situation of the city is described and evaluated

- different emotions conveyed in subsequent utterances. ${ }^{9}$

6 Koenen discusses the issue of the unity of each of the poems in a separate paragraph entitled "Aufbau" (see Klagelieder, 21-25; 108-112; 206-209; 312-315; 377-378). He concludes that each of the poems is characterised by inner logical development (see pages 21 and 379).

7 Lanahan's position on the issue of unity of Lamenations is still authoritative: “... the variety of voices sketches the topography of a unique spiritual consciousness, which can realize itself only by projecting its grief in its constituent phases by adopting different personae. This ultimate unity should emerge as a single controlling awareness from the detailed examination of the five personae to which we shall now proceed?" ("The Speaking Voice," 42).

8 Inhis description of this literary device, Lanahan("The Speaking Voice,"41) uses the classical Greeknotion of persona, in order to emphatize its function of presenting different points of view on the same events. From the perspective of the author-reader communication strategy, the 'voices' speaking in the book should not be confused with the author of the Book, or with any other real person. This strategy can be reframed as presence of different implied authors, i.e., authors conceptualized by the reader in the process of reading, in different passages of the book.

9 See Obara, Lamentazioni, 17. According to her, this strategy makes it possible for the voices to become models for people distant both in time and in space from the tragic events, which happened in 
At the beginning of the first poem (Lam 1:1-9b) and then in other passages in Lam (see e.g. 2:2-13 and 4:1-10), a person who seems to be an observer is speaking. He reports the dramatic events and focuses on their meaning, rather than on their dramatic course,${ }^{10}$ with a passionate and highly engaged voice of someone who participates in the suffering of others.

Another voice belongs to Jerusalem, hidden behind a female figure (see e.g. Lam 1:12-16;2:20-22 and others). Yet another voice, filling the third poem (Lam 3), is a male one, speaking both on its own behalf and on the behalf of the community. Finally, the voice of those who survived speaks in a collective prayer of Lam $5 .^{11}$

The voice speaking at the very beginning of the third poem is a male one:

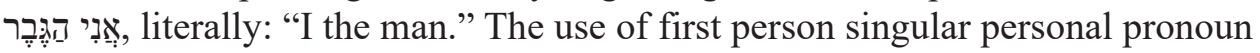
clearly demarcates the speaker's utterance, which lasts, at the first glance, until v. 21. Afterwards, there is a series of changes. At first, there is a transition to first person plural in v. 22: "We have not come to an end, been consumed." 12 Then, to third person singular in v. 25: "The Lord is good to those who wait for him, to the soul that seeks him." In v. 40, there is a return to first person plural: "Let us test and examine our ways and return to the Lord." The first-person singular form from vv. 1-21 returns only in v. 48. These utterances are similar to those in the first (Lam 1) and second (Lam 2) poem. Some of the commentators interpret this similarity as an indication of another speaker, e.g. the city, whose voice contrasts in these verses with that of the man. ${ }^{13}$ However, these multiple changes of grammatical number should not be interpreted as a change of the voice, but rather, as a change of function of the same voice of the geber. In vv. 1-21, it is the voice of someone who, experiencing the suffering sent by God, participates in the suffering of the city and who, assuming the role of a teacher, reflects on

Jerusalem in 586 BC. Despite this distance, they can become close to any reader, through the universal experience of human suffering. The voices achieve this "universal closeness" and reduce it to a number of types, or models, which allow for an even closer identification and for expressing the reader's own painful experiences in a language form. The speakers bring out the reader from the tragic isolation experienced by each suffering person: "How lonely sits the city ...." (Lam 1:1). See also Kang - Venter, "A Canonical-Literary Reading of Lamentations 5," 1f.

10 Carleen Mandolfo, owing to the distanced tone of the first voice, classifies it as a "didactic voice" (see Daughter Zion Talks, 60-65, 69-76), but not in a depreciative sense, suggesting soulnessness or insensitivity. This 'voice' can only be interpreted correctly in the wide context of 'voices' audible in other biblical texts, especially in the Psalms, prophetic text and Lamentation. See the same author's earlier publication, God in the Dock. Dialogic Tension in the Psalms of Lament (London: Sheffield Academic Press 2002) 9-27 and also Daughter Zion Talks, 60-64, including the analysis of Ps 7.

11 Some researchers consider also other speaking voices, but their presence is either uncertain and depends on the interpretation of the text, or no wider consensus has been reached in this regard.

12 See Koenen, Klagelieder, 194.

13 See H.J. Boecker, Klagelieder (ZBK.AT 21; Zürich: Theologischer Verlag 1985) 69, I. Provan, Lamentations. A Commentary, 2 ed. (Vancouver: Regent College Publishing 2016) 81. 
the painful events, in which human life becomes tragically affected by God's violent actions, in vv. $25-39 .{ }^{14}$ Finally, in vv. 40-47, through the artfully constructed prayer, it becomes the voice of the repenting community. ${ }^{15}$ As has been mentioned above, many of the formulations in the third poem resemble these from the first and second poem, in which they belong to the figure of Zion (see e.g. 3:1 and $2: 2 ; 3: 3$ and $1: 20 ; 3: 4$ and $2: 2,5 ; 3: 14$ and $1: 7 ; 3: 15-16$ and $1: 11 ; 2: 20 ; 3: 48$ and $1: 16$ a etc.). Nevertheless, this similarity does not signify the speech of the female figure from Lam 1 and 2. Rather, it indicates the degree to which the dominant voice of the third poem, i.e., that of geber, identifies with her.

\subsection{The geber as the Leading Voice of Lam 3}

The singleness, uniformity and, at the same time, polyphony of the speaking voice in the third poem make this text unique in the context of the book and, because of other literary characteristics, its true centre ${ }^{16}$ Both the content and the metaphors remain coherent and develop throughout the third poem, notwithstanding its clear inner divisions (see vv. 18 and 19; 39 and 40; 51 and 52). The images frequently change; one part of the verse relates to what precedes it, the second one is in contact with the following verses. As a result, the poem presents an undeniable development of its message, maintaining at the same time its inner coherence. ${ }^{17}$ This does not make reading the text any easier: it forces the reader's focus, but it also has the effect of constant freshness, even though this part of the book is considerably longer than any of the other four poems. This way, the third lament becomes the real centre of the whole book.

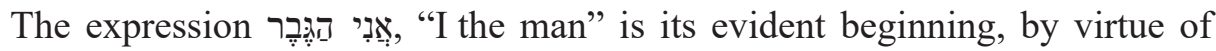
the emphatic use of the first person singular personal pronoun, indicating a clear distinction between this verse and the conclusion of the previous poem. The use

14 See Koenen, Klagelieder, 207.

15 Scholars differ in their opinions regarding the extent of the prayer section in Lamentations 3, and the nature of each of its stages. E.g., Obara (Lamentazioni, 108) locates its beginning in v. 40 and indicates its three parts: vv. 40-47 (exhortation), vv. 48-51 (lamentation and prayer of intercession) and vv. 52-66 (supplication). Similarly Koenen, Klagelieder, 208. On the other hand, Provan (Lamentations, 83f), notices a departure from the prayerful tone towards reports of the man's individual situation in the last section, vv. 52-66.

16 Already the superscription of the book in LXX, attributing its authorship to Jeremiah, indicated the book's unity. Today scholars are inclined to support this view, but the character of this unity and its internal dynamic whether the book has a central point, and whether it reaches its climax in the conclusion remain under discussion. In the present article, I accept the hypothesis that the book's central point is situated in Lam 3. See Koenen's discussion of different possibilities, in Klagelieder, 38*-43*, including his own view, based on the consideration of literary and historical arguments, on page $45^{*}$.

17 See Berlin, Lamentations, 86f. 
of the pronoun is also connected with the basic literary characteristic of Lam, that is, the acrostic form of its initial four poems.

Poems in the chapters 1,2 and 4 begin with an anacrusis אִיכָ, "how?!" It expresses the speaker's astonishment at the events he witnessed, resulting from the contrast between the tragic state of the city and its earlier condition. However, "how?!" has an additional meaning. The tragic situation goes beyond what could have been imagined about the city's destruction and the fate of its inhabitants. Moreover, the way in which the enemy and destructor of the city is identified changes in the third poem in comparison to the preceding two poems. This indicates the growing awareness that it is God himself! In Lamentations היכָ conveys shock and expresses scandal. Even though, as it has been mentioned, the third poem begins with the personal pronoun, it does not mean that this tone has been abandoned. To the contrary, the poem will shortly turn out to be its consequence, continuation and even a shocking development.

The presence of the first person singular personal pronoun in Lam 3:1 announces the autobiographical tone of this and following verses (vv. 1-24). It makes them an expression of a personal experience of the speaking "I":

\section{I am the man who has seen affliction under the rod of his wrath; \\ 2 he has driven and brought me into darkness without any light; \\ 3 against me alone he turns his hand, again and again, all day long. \\ [...] \\ 24 YHWH is my portion says my soul "Therefore I have hope in Him"}

Different configurations, in which parts of speech, such as personal verbal forms, prepositions with personal pronoun and nouns with possessive pronoun, occur in this passage in first person singular, all emphasise the personal and radical character of the experiences reported by the speaking voice.

It has been mentioned that their meaning goes beyond endowing these verses, and consequently, the larger unit constituted by the complicated structure of the third poem, with a personal character. The opening verses of the third poem stand in sharp contrast to the preceding poems. This contrast is not founded on the comparison of their contents. The third poem, like the previous two, gives an account of the dramatic events, which affected the inhabitants of Jerusalem and its surroundings. Also in the initial two poems, another voice leaves the detached tone of someone merely reporting the dramatic state of the city after the long siege and finally, its collapse, and transitions to empathy - deep

18 See T.H. Robinson, “Anacrusis in Hebrew Poetry," Werden und Wesen des Alten Testaments. Vorträge gehalten auf der Internationalen Tagung alttestamentlicher forscher zu Göttingen vom 4-10 September 1935 (eds. P. Volz - F. Stummer - J. Hempel) (Berlin: Töpelmann 1936) 39. 
emotional engagement and participation in the fate of the city and its inhabitants (Lam 1:1-11;2:2-10). ${ }^{19}$ However, it is only in Lam 3:1 that the speaker expresses himself as 'I,' and the full meaning of this is revealed in the term with which it constitutes a syntactic compound the man.

The significance and power of this compound result not only from the meaning of the term itself. ${ }^{20}$ Basing on the Old Testament phraseology and its source, i.e. the root $g b r,{ }^{21}$ its denotation has been reconstructed as 'a strong, young man. ${ }^{12}$ In Ps 127:5, the term is woven into a double context in which masculinity is emphasised:

\section{Happy is the man [הֶֶָּ] who has his quiver full of them}

He shall not be put to shame when he speaks with his enemies in the gate.

The metaphor of a quiver combines two spheres of mature masculinity: fertility and readiness for warfare. The significance of the latter as a component of the term is emphasised by the preceding verse 4 , with which v. 5 is strongly connected:

\section{Like arrows in the hand of a warrior [רiּ彐] are the sons of one's youth.}

The presence of the term רiּa, referring directly to the figure of a warrior, indicates a similar connotation of the former term. The link between the figure of geber with the military world, indicated in the discussed verses, seems be its natural extension. It is only when we consider the above that both the basic meaning of the term and the connoted vitality and mature masculinity are fully revealed in the speaker's self-identification. ${ }^{23}$ But the issue becomes even more

19 See note 18. In his essay, to which I refer there (in the paper quoted at fn. 18), Robinson argues that the expression איָָ, apart from its nominal meaning, has the additional function of indicating the subject's emotional state. By means of this expression, the speaking voice expresses his perturbation and bewilderment at the city's situation.

20 Koenen (Klagelieder, 214-220) discusses the complexity of the history of interpretation of this term in Lm 3:1. The German scholar groups the existing interpretations into three categories: individual (Individuelle Deutung), collective (Kollektive Deutung) and universal (Jedermann). The two initial categories are rejected as faulty, due to their focus on addressing the question "who is the speaking 'I'?," without paying adequate attention to the text and the term's closest context. Therefore, following Koenen (Klagelieder, 221) and a number of other commentators, (see. e.g. Obara, Lamentazioni, 86-87, not considered by Koenen), in this study it is accepted that "in der Person, die nicht mit einem bestimmten Menschen zu identifizieren, sondern als literarische Schöpfung zu verstehen ist, bietet der Dichter seinen Leserinnen und Lesern eine Identifikationsfigur an."

21 See J. Kühlewein, “gbr,” TLOT I, 299 and H. Kosmala, “gabhar,” TDOT II, 367.

22 See HALOT, 1563.

23 See Kosmala, "gabhar," 379: "gibbor must be understood figuratively, and once again gebher has reference to the virility of his youth." See also Ps 88:4 above, with the expression "like a man without strength," suggesting a man deprived of his characteristic strength and confidence. See G. Ravasi, Il Libro dei Salmi. Commento e attualizzazione (Bologna: EDB 1993) II, 814. 
complex when we consider the distribution of this term in the Hebrew Bible. Rather than in the historical books, it occurs most frequently in poetry and sapiential literature, ${ }^{24}$ where it assumes yet another meaning: it indicates a man, who remains in a special, close, and intimate relationship with God. This relationship finds its expression in following God's will (Prov 30:1; Ps 40:4,8) which does not mean that the man is exempt from suffering (Ps 88:4,48). ${ }^{25}$ Even is such moments he continues to call out to the Lord, day and night, in the hope of being heard (Ps 89:2). It is precisely this meaning of the term that is best fitting with the immediate context, where the geber is confronted (as will be shown later) with the hostile attitude of God and with the further context, which speaks of the hope that remains preserved (Lam 3:18-24). The awareness of this complexity of the geber figure, activated at the beginning of the third poem, is a condition of correctly interpreting the text, not by discovering the wealth of its meaning revealed at subsequent stages of the text, but rather by noting its radical rejection occurring throughout the poem.

\section{3. 'I, the geber': Questioned Identity}

Already at the beginning of the third poem, the wealth of meaning of the geber figure belongs to the past. The aim of the nominal sentence, with the emphatic personal pronoun as the subject and the term as the predicate, is to establish the identity of the geber ${ }^{26}$ In this way, the speaker differentiates himself from any other geber. In ancient royal documents, nominal sentences beginning with ' $I$ ' introduce a series of sentences justifying the titles introduced in the nominal sentence. However, this is not the case in Lam 3. On the contrary, the speaker, identifying himself as "I-the man" (warrior, hero, strong man), points at himself as someone incapacitated in this very respect. ${ }^{27}$ This is demonstrated in the first part of the poem, vv. 1-21, autobiographical in character, and in the subsequent nominal sentence, v. 63. The initial self-identification organizes the whole third poem in its complicated literary development, noted above.

24 While this word occurs in the OT 66 times in total, 35 of these occurrences are found in Hi, Ps and Prov.

25 See Kosmala, "gabhar," 379, who mentions even a 'new meaning' of this term and develops his reasoning in the following words: "The Word gebher receives a far-reaching New meaning: a man is called gebher, when he stands in an intimate relationship with God, trusts and fears God, and does what God requires of him."

26 See P. Joüon - T. Muraoka, A Grammar of Biblical Hebrew (SubBi 14; Roma PIB 1991) § 154ea; Koenen, Klagelieder, 221.

27 See Berlin, Lamentations, 84: "It may be that the beginning of the chapter 3 is imitating an accepted literary convention. If so, that convention has been turned on its head, for instead of self-glorification, we find self-abasement." 
In his self-identification as a strong man, a warrior, the speaker is confronted with the experiences of suffering ("who has seen affliction" ראה עני v.1a) and with violent actions of a third subject ("the rod of his wrath" בשבט עברתו v. 1b). The first of these expressions resembles the invocation to God in Lam 1:9: ראה יהוה את־עניי, which in turn echoes similar supplications, in which God is pleaded to notice the situations of suffering and oppression, see e.g. Gen 29:32; 31:42; Exod 3:7; Deut 26:7; 1 Sam 1:11. The use of this phrase in Lam 3:1 is unusual for two reasons. Firstly, its subject is a man, rather than God. Secondly, the meaning of the verb "to see" ראה is broadened and takes on the meaning "to experience, to know," instead of "seeing" in the physical sense. The encounter with suffering is presented as an extreme experience, encompassing a person, here, the geber, to the very centre of his being and self-identity as "I-man."

The second part of the discussed expressions, "the rod of his wrath," includes the possessive pronoun "his" referring to God, who only in v. 19 is addressed by his name. This expression indicates that the geber did not experience God's favour adequate to their intimate relationship. On the contrary, he suffered a punishment, represented with the metaphor of the rod. This is the kind of punishment that a slave could receive from his master (see Exod 21:20). The power of this phrase and the hostility it expresses are confirmed by the words "he has driven and brought me into darkness without any light" v. 2; "against me alone he turns his hand" v. 3, and the following verses. The experience of God's hostility is accompanied by being an object of scorn of the speaker's own nation: "I have become the laughingstock of all my people" הייתי שחק לכל־עמ v. 14a. The latter confession takes on the form of another (after v. 1) self-identification in v. אני מנגינתם 63 "I, their mocking song." The mockery of this self-identification is present also in the words "I, the geber."

The voice self-identifying as "I, the geber" bears a strong relation to the series of situations and actions discussed above, which were caused, from the literary perspective, by an anonymous/unnamed subject. The oppressive and relentless actions of the latter are accurately directed against the self-identification of the man as someone strong, a warrior, a hero. In this way, they are in brutal synchrony with this self-identification, but they are not aimed at exercising and refining it, but rather, at negating it. The voice's response to "his" (see v. 18) consistent and precise actions is a series of confessions: ותזנח משלום נפשי "my soul is removed from peace," v. 17a, נשיתי טובה "I have forgotten what happiness is" v. 17b, "my glory and my hope have perished” v. 18a. They do not denote only surrender or withdrawal. Each of them: שלום, טובה, נצח and refer to what constitutes the man in his relationship with God. Lack thereof denotes the loss of the foundation of this relationship. It is only from this perspective that we can grasp the meaning of subsequent stages as the poem unfolds. 
The disruptions in the use of verb tenses and changes of style pointed out by commentators are interpreted correctly as the speaker's transition from hopelessness to hopefulness (see. vv. 21,24). ${ }^{28}$ However, such a transition becomes possible only after the speaker's identity has been questioned. But its complete rejection does not encourage its reconstruction. It is not the geber who remains in a relationship with God and his people, equally to the speaker subjected to suffering (vv. 40-66).

Verse 40 marks a transition to a new type of utterance. This newness results from the use of first-person plural, "we" (vv. 40-42) instead of "I" and addressing God with a direct "you" instead of "him" (vv. 42-45). Admittedly, the "not-geber" on one occasion returns to the "I" (vv. 48-62), which could be interpreted as an indication of a return to the situation from the beginning of the poem, i.e., reporting the suffering experienced by the speaker. However, a careful reading will reveal that the ' $I$ ' that occurs here in the context of a prayer (vv. 40-47), does not expresses "the suffering of the affected" (das Leid des Betroffenen), but rather "the suffering of the beholder" (das Leid des Betrachters), who witnesses the tragic fate of the city (v. 48.51). ${ }^{29}$

This new, but not another, return to the experience of misery is followed by a new way of speaking about God. This time, instead of the tone of contempt and rejection (v. 1),${ }^{30}$ there is an invocation of his name as the one who brings salvation: "I called on your name, YHWH, from the depths of the pit" v. 55; ראיתה יהוה עותתי שפטה משפטי "You have seen the wrong done to me, O YHWH; judge my cause" v. 59. The tone of these utterances is different than that in the first part of the poem and indicates that the speaker has travelled a journey of an inward change, which began with the questioning of his identity as the geber.

\section{Review of the Voices in Lam}

Dealing with the figure of the geber, I focused on two aspects: firstly, its characteristic as a speaking voice and secondly, one whose identity is questioned. Both aspects are tightly connected with the closest literary context of the third chapter of the Book of Lamentations. However, despite my focus on the third poem, the dynamic of the conducted research meant that the remaining poems of which the book consists had to be considered as well.

\footnotetext{
28 See Lanahan, “The Speaking Voice,” 46; Provan, Lamentations, 81; Obara, Lamentazioni, 86.

29 See Koenen, Klagelieder, 275.

30 See Korzec, "I-the Strong Man," 80-84 for my discussion of the component of contempt in the expression 'his wrath' is this verse. For more on God's wrath in the prophets, see W. Pikor, "The Motif of God's Wrath in Zephaniah's Prophecy about the Day of Yahweh," BibAn 4/1 (2015) 41-55.
} 
Already the first of the characteristics, being a voice, situates the geber among many other speaking voices in the book. This opens two possibilities: the geber can be either independent from the other voices or remain in a 'dialogue' with them. Both alternatives provoke further questions, e.g., regarding its significance from the perspective of the book's unity, undeniable, albeit achieved in the process of composition. ${ }^{31}$

The literary characteristics of the third poem which make it distinctive from the other ones, and especially the presence of only one voice, in contrast to two clearly distinguishable different voices, male narrator and female city, speak in favour of the first hypothesis, i.e., independence of the voice of the geber. The hypothesis of an interaction between the voice of the geber and the voices of the narrator and the city can be supported with firstly, the discussed characteristic and secondly, with the presence of certain coherence in the utterances of the voices. Namely, the narrator, the city and the geber circulate around the experience of suffering and the role of God in allowing it to happen. At the same time, the voice of the geber stands out against this background because of its radical self-identification (Lam 3:1), as discussed above. Its precise aim is to emphasise that the narration of the voices has reached its climax. From this perspective, I will suggest several links between the third poem and the preceding and following ones.

\subsection{Lam 1-2: Voices of the Narrator and the 'Voice' of the City}

As it has been indicated above, for several researchers the presence in Lam 3 of images introduced in the preceding poems (Lam 1 and 2) became in Lam 3 the basis for linking the voice of the geber with the female voices present in Lam: the Daughter of Zion and Daughters of Jerusalem. Both are metaphors for the city. ${ }^{32}$ This proximity has led some of the scholars to argue that the voice of the geber is not a voice of a particular person, but rather that of Zion or its

31 See Koenen, Klagelieder, 38*-43*.

32 Apart from sections and chapters in commentaries on Lamentations, addressing the issue of female metaphors, (see e.g. Berlin, Lamentations, 7-15; F.W. Dobbs-Allsopp, Lamentations [Louisville, KY: John Knox Press 2002] 33-36, 41-44), the following studies deserve mention: Heim, "The Personification of Jerusalem," 129-169; Mandolfo, Daughter Zion Talks, 79-120; N.C. Lee, "The Singers of Lamentations: (A)Scribing (De)Claiming Poets and Prophets," Lamentations in Ancient and Contemporary Cultural Contexts (eds. N.C. Lee, C. Mandolfo) (Atlanta, GA: Society of Biblical Literature 2008) 45-46; M.L. Conway, "Daughter Zion: Metaphor and Dialogue in the Book of Lamentations," Daughter Zion. Her Portrait, Her Response (eds. M.J. Boda - C.J. Dempsey - L.S. Flesher) (Atlanta, GA: Society of Biblical Literature 2012) 111-126. 
people in the collective sense. ${ }^{33}$ However, the discussed context of chapter 3 does not justify such an interpretation.

The images of the city's suffering in the first and second poem are similar to those in the third poem. However, there is a difference between them, which does not result from their content. The images in the third poem, reporting the dramatic events, which affected the inhabitants of Judah and Jerusalem, reflect their descriptions in the first two poems. Also in this case the speaking voice abandons the distanced tone with which it describes the tragic state of the city following the long siege and the subsequent fall, and moves on to empathy, which is a participation in its fate $(2: 11-13)$. But it's only at this point, in Lam 3:1, that the voice speaks as, "I," harmed in what he regards as the expression of himself: being strong. The erasure of this quality makes it impossible for him to help the city and its inhabitants in their tragic situation. The self-identification at the beginning of the first poem, with the following autobiographical description of suffering, keeps on the descriptions from the preceding poems and it also underlines the finality of the state of collapse and destruction to which they refer. No human power or strength could have stopped the catastrophe, and neither can it reverse its consequences. The only things left to do, is to move the unmoved, the One who had chosen Jerusalem and now irrevocably rejected her, as indicated in the second poem, and especially in its moving conclusion.

In Lam 2, like in Lam 1, there are two speakers: the narrator and the city. However, in Lam 2 the former dominates over the latter. His voice fills the initial nineteen verses. The voice of the city is audible only in the conclusion of the poem (vv. 20-22). ${ }^{34}$ Also, the tone of his utterance differs slightly from the one in the first poem. In the former, the terrifying situation of Zion, the city, is emphasised, but in the latter, the task of the 'voice' is to indicate that it is YHWH who has caused the situation of the city. His actions, undertaken in untamed wrath (vv. 1a,1b,3,4,6), absorb the narrator's attention and fill the 'narration' with a series of descriptions of destructive actions. God's destructive actions leave the foreground only briefly, in vv. 9-12, where the descriptions of the state of Jerusalem return. The emotional outburst of vv. 11-12 is not directed against God, but rather is a transition to the heated speech directed at the second of the addressees, i.e., Zion. Only in the following words the thought returns that the destruction, violence, and rapes are the result of God's actions, even though the city is being 'devoured' (compare v. 16) by its enemies. Against this background the Daughter of Zion is summoned to pray for relief (vv. 18-19).

33 See e.g. B. Albrektson, Studies in the Text and Theology of the Book of Lamentations with a Critical Edition of the Peshitta Text (Lund: Gleerup 1963) 126-128 and H. Gottlieb, "Das kultische Leiden des Königs: Zu den Klageliedern 3,1," SJOT 1/2 (1987) 121-126.

34 See Berlin, Lamentations, 76-77; Obara, Lamentazioni, 62; Koenen, Klagelieder, 108-110 and 110-112, where he discusses other possible divisions of the second lamentation. 
Verses 20-22 contain Zion's concise reply. Contrary to the conclusion of the first poem, where Zion speaks as well, the lack of resolution of the prolonged suffering leads the city to the utterance of an accusation, which gives expression to helplessness. Words filled with terror are uttered (v. 22):

ולא היה ביום אף־יהוה פליט ושריד אשר־טפחתי ורביתי איבי כלם

"those whom I bore and reared, You, my enemy, have brought to an end!"35

The exclamation my enemy is a new, unprecedented identification of YHWH. Until now, he has been regarded as the one who acts as an enemy (compare vv. 4,5). Its significance is fully appreciated by the speaker; therefore, it remains unspoken, imprecise, open to interpretations, and even anonymous. As indicated by the possessive pronoun in the בשבט עברתו (Lam 3:1), the shocking meaning of the exclamation becomes a starting point for the proposed new kind of relationship between God and His people, presented in the third poem.

The third poem, by the means of the figure of the geber and his initial self-identification, departs from the anonymous figure of the narrator and harmonizes with the radical response of the city, reaching its climax in v. 22b. It demonstrates that the narrator from the first and second poem, in his reports of the enemy's violence and even in the correct identification of its initiator, does not reach the depth of the victim's emotions, expressed in the exclamation "my enemy!" It is only possible for him, the geber, faced with the reality of suffering (vv. 1-18) and struggling to explain what has occurred within the framework of the categories of faith (vv. 19-20) and to keep his hope amongst despair (vv. 21-24). Like the majority of those who suffer, he balances between contradictory experiences; he complains and doubts (vv. 37-39). Immediately afterwards, he moves to expressions of hope and states that silence and patience are good; he encourages himself and others to reflect and pray (vv. 40-43), and having recovered, he begs for revenge (vv. 58-60) and finally (vv. 64-66), in a tone as radical as the concluding exclamation of the second poem, he proclaims:

\footnotetext{
${ }^{64}$ Pay them back for their deeds, O YHWH, according to the work of their hands!

${ }^{65}$ Give them anguish of heart; your curse be on them!

${ }^{66}$ Pursue them in anger and destroy them from under YHWH's heavens. ${ }^{36}$
}

35 The Masoretic Text preserves here the singular noun form 'ōybî (v. 22c), while LXX, the Syriac version and the Targums prefer the plural form. The latter indicates enemies in general and the singular form is a definite reference to God. See Koenen, Klagelieder, 104.

36 The final three verses of Lam 3, especially v. 65, present a number of difficulties resulting from the history of the text and its exegesis. They are discussed at length in commentaries. See e.g. Provan, Lamentations, 109 and Koenen, Klagelieder, 199. 
He makes God, the cause of his defeat, the champion of his and his city's cause.

Simultaneously, he is compared with the narrator and in confrontation with God. His self-presentation as "I-the (strong) man" contrasts his powerless and broken self with the figure of God the warrior introduced in the second poem. ${ }^{37}$ In contrast to the God-warrior-winner, triumphing over Zion, he, the geber, is the one who 'saw-experienced' the suffering (Lam 3:1). As a witness, he can address the Other Warrior with contempt: 'his wrath,' rejecting any claim to further influence on the faith of the nation the latter may have. This conclusion does not end the speaker's dialogue with Him. Defeated and deprived of the deceptive power of human strength, he discovers the true meaning of "the rod of his wrath." It does not confirm God's sovereignty on the rubbles of human strength. Its severity and ruthlessness invite the speaker to turn to Yahweh yet again, who, because of his faithfulness to his covenant, has gone on the warpath against His people.

\subsection{Characteristics of voices in Lam 4-5}

Comparing the relation of the figure of the geber with the figures from the fourth and fifth poem, we must consider the literary characteristics of both texts, which make them significantly different from the preceding sections of Lam. Firstly, the length of stanzas of both concluding poems of the book is significantly different from the preceding parts of Lam. Secondly, in the fifth poem, the acrostic structure disappears, while the number of verses is maintained. These two formal features of the text are meaningful. After reaching its climax in the third poem, the book slowly approaches its conclusion. Numerous words and rapidly changing images are replaced with a balanced, restrained tone, and, from the religious perspective, with confidence that earlier prayers (Lam 2:20-22; 3:64-66) were heard and will soon be answered by God (compare e.g. Lam 4:21-22).

The speaking voices in both poems are no less significant. The narrator returns in the fourth poem and reports the situation as an external observer in vv. 1-16 and 21-22. For a short moment, in vv. 17-20, his utterance is interrupted by another voice. First person plural may indicate that this new speaker is either the community of the city's inhabitants, or an individual speaking on its behalf. ${ }^{38}$

Both voices are characterised by simplicity in their description of the suffering they encounter "on the streets." ${ }^{39}$ The voice of the narrator once again (comp. vv. 11-16) makes the effort to understand the reasons of the tragedy and within

37 See Korzec, "I-the Strong Man," 81-84.

38 See Provan, Lamentations, 109; Obara, Lamentazioni, 119; Koenen, Klagelieder, 312.

39 The prepositional phrase בחוצות occurs in Lam 4 three times, see vv. 5,8,14, and the noun חוצ occurs also in v. 1. Moreover, the term רחב, "street," or "square," see v. 18, belongs to the semantic field of urban topography. 
the framework of classical concepts he stresses the sin of the people, and especially of its religious leaders (v. 13). Furthermore, the voice of the community of the city's inhabitants, whose all hopes failed: "Continually we kept watching our eyes for our help, in vain" v. $17 \mathrm{a},{ }^{40}$ expresses disappointment because of the lack of help from the external allies (v. 17b), and especially from the internal institutions, whose quintessence is the figure of the king, God's anointed one (v. 20a). Both voices are in harmony in their description of "the total collapse of the state, as a nation, as a people, and as a culture." ${ }^{\prime 1}$

The narrator's utterance at the end of the fourth poem is characterised by confidence, unprecedented in other parts of Lam, regarding the city's "bright" future (v. 22a) and God's imminent punishing intervention, which will affect the enemies (v. 22b). However, this is only a brief pause, and the painful experience of reality returns immediately afterwards, in vv. 2-18 of the following, fifth poem. Therefore, the meaning of the concluding verses of the fourth poem should be considered in the context of the preceding passages.

The fourth poem is characterised by an atmosphere distinct from that of Lam 1-3 and especially Lam 3 . The speaking voices in these poems presented the situation of the immediate aftermath of the successful attack of the enemies, who achieved their destructive goal. At that time, despite the destruction, there was still some hope for salvation. On the other hand, now, in Lam 4, the "end" has come, and it is marked by the exhaustion of both: God's wrath and the people itself. ${ }^{42}$ The consummation of the punishment, proclaimed in the final verse, is an important novelty, but it does not immediately become an object of hope: it does not foretell the return to the situation preceding the outburst of the divine wrath. This new "atmosphere" indicates that the voices in the fourth poem, even though they belong to the narrator and the city, familiar to the reader from the first and second poem, are now in a different situation. They speak in a new context, and the speakers themselves have travelled a long inward journey.

The fifth poem differs from the remaining ones in that the acrostic structure has been abandoned. Nevertheless, the number of verses, i.e. twenty-two, reflects the number of characters in the Hebrew alphabet. The fact that the acrostic is abandoned in the fifth poem is not completely unexpected. The orderly acrostic structure in the first four poems was broken regularly after the letter 0 , which in the Hebrew alphabet is followed by the letter ע. Already there, the strait-

40 The Hebrew text in this place has Ketiv/Qere עודינה/ עודינו, see Koenen, Klagelieder, 307.

41 See Lanahan, "The Speaking Voice," 47, who notes the presence of an additional voice in the fourth poem. On the other hand, Obara, Lamentazioni, 119; Koenen, Klagelieder, 313 note a presence of another female voice of the city in vv. 17-20.

42 The vocabulary of the fourth poem, including terms such as כלה " כלה "come to an end" (see vv. 11,14) "end" (v. 18 x 2) and expression מלאו ימינו "Our days were finished" (v. 18) and others, are evocative in this respect. 
jacket of the acrostic form bursts under the pressure of the dramatic content of the poem, centred on the unimaginable and inexpressible destruction, resulting from God's rejection. In the fifth poem, this pattern changes, as the situation of destruction is no longer accepted. The fact that it is prolonged calls for a different strategy; departing from the alphabetical structure of the text is the first response to this need. ${ }^{43}$

The content of the fifth poem corresponds to the rest of the passages in the book and the most obvious connection is its link with the fourth poem, whose conclusion gave rise to certain expectations. ${ }^{44}$ Nevertheless, already the initial stanzas of Lam 5 allow us to understand that the high hopes for the future were not materialising. This folk lamentation ${ }^{45}$ opens with an urgent supplication directed to God (v. 1):

Remember, O YHWH, what has befallen us; look, and see our disgrace!

It announces the main theme of the poem: 'our disgrace' (v. 1b). The presence of the first person plural personal pronoun allows the reader to identify the collective voice "we," who speaks throughout the poem. ${ }^{46}$ The "we" of the poem is the "we" of the defeated, oppressed and dispersed people of God (compare vv. 2-18). From v.2 a long section begins, lasting until v. 18, in which the humiliating situation of the city and its people is presented. Vv. 19-22, serving as the poem's conclusion, contain the final supplication. ${ }^{47}$

The persistent returns to the themes of destruction and the resulting mourning, and the experience of complete abandonment by God - they all must reach its end. However, it will not come because of "work" of the community experiencing these situations. The awaited change can only come from God and it

43 See Obara, Lamentazioni, 31. See the following brief and accurate characterisation of the connection between the poetic form and the message of the fifth poem in Reinhard Feldmeier i Hermann Spieckermann (Der Gott der Lebendigen. Eine biblische Gotteslehre [Topoi Biblischer Theologie 1; Tübingen: Mohr Siebeck 2011] 369): "astetische Visualisierug der Not der Vaterlosen." Koenen discusses the poetic form of the fifth poem in Klagelieder, 375-377. See there also for a comprehensive bibliography.

44 For a broader discussion of the relation of Lam 5 to other chapters of Lam, see R.B. Salters ("The Unity of Lamentations," IBS 23 [2001] 105-107) who emphasizes the connection of Lam 5 with Lam $1 ; 2$ and $4 .$.

45 See M. Emmendörffer, Der ferne Gott. Eine Untersuchung der alttestamentlichen Volksklagelieder vor dem Hintergrund der mesopotamischen Literatur (Tübingen: Mohr Siebeck 1998) 39-76 (especially 64-76); M. Emmendörffer, Gottesnähe. Zur Rede von der Präsenz JHWHs in der Priesterschrift und verwandten Texten (WMANT 155; Göttingen: Vandenhoeck \& Ruprecht 2018) 8f, Provan, Lamentations, 125 and Koenen, Klagelieder, 378.

46 See Provan, Lamentations, 123f; Kang - Venter, "A Canonical-Literary Reading of Lamentations 5," 2; Obara, Lamentazioni, 31.

47 See Obara, Lamentazioni, 137; Koenen, Klagelieder, 377. O'Connor (Lamentations and the Tears of the World, 72) suggests that the text consists of two parts: vv. 1-8 and 19-22. 
is impossible to plan it; it can only occur if God changes his attitude towards the community whom he himself broke up. This state of absolute dependence on God is expressed in the "thinning" of the text of the fifth poem. It is not the human words, of which until now there have been too many, that will bring this tragic situation to an end. The decision regarding the change belongs to God. The community of the rescued is expected to react in a positive way to God's "repentance."

The conclusion of the poem, uncertain on the level of the text's transmission and the reception of its message, consists of a record of doubts experienced by the community affected by the tragic events. ${ }^{48}$ It is in this context that the final call for repentance is uttered (v.21). The road leading to it is a long one. Is it possible to still trust God while facing the prolonged experience of evil? Did the experience of the enormity of suffering leave any space for turning back to him? Indisputably, the faith that he is the Saviour is present in the consciousness of the people, but won't he turn away from them once again, considering that his actions have been expressed through the burning heat and crushing burden of his wrath?

\section{Conclusion}

The review of the voices in Lam presented above highlights the characteristic of the voice of the geber. First, he is distinguished by a self-defined identity: 'I, the man.' Neither the singular 'voice' of the narrator nor the collective voice of the city resort to such a clear identification. The self-identification acquires an additional significance through the fact that in a few of his utterances the geber is harmonized with other voices. Like the narrator, he describes the destruction of the city and the tragic fate of its inhabitants. Like the other voices that's to say the narrator, and the city, he turns to God. Like the narrator, he makes himself a participant of the events through empathy, and together with him and with them he looks to God for help. The self-identification does not strengthen these attitudes. It acquires significance only in the context of being a marker of the identity questioned in the confrontation with "the rod of His wrath" (Lam 3:1).

The fact that the identity of the geber, a powerful and wise man, is questioned, indicates that the obvious identity of the city as the Daughter of Zion (see e.g. Lam 1:6; 2:1), Daughter Jerusalem $(2: 13,15)$, the Daughter of Judah (see $1: 15 ; 2: 2$ ), Daughter of my People (e.g. $2: 11 ; 3: 48$ ), which from this posi-

48 See Provan, Lamentations, 134: "the poem does not have a confident ending, and it is difficult to see how it is that so many commentators have come to the conclusion that it does." 
tion turns to God, also reveals itself as questioned (Lam 5). Therefore, the third poem is the turning point in the book of Lamentations, accentuated by the discussed poetic form and by its content. The voices of the narrator and the city, speaking in the first two poems, do so within the roles suitable for them, known from other biblical books. After the third poem the content of their utterances changes.

In the conclusion of the fourth poem, the crucial figure of the Daughter of Zion makes her final appearance. The narrator addresses her with the proclamation: "The punishment of your iniquity, O daughter Zion, is accomplished" (v. 22a). She is mentioned eight times in the whole book $(1: 6 ; 2: 1,4,8,10,13,18$; 4:22) and additional formulas, such as Daughter of Judah, Daughter of Jerusalem, Daughter of my people, or Daughter of my city, occur in $1: 15 ; 2: 2,5,11,15$; $3: 48,51 ; 4: 3,6,10 .{ }^{49}$ Moreover, as a voice she dominates in parts of the first (vv. 12-22), second (vv. 20-22) and fourth poem (vv. 17-20). She is significant in the whole book. ${ }^{50}$ Considering the above, her absence in the fifth poem appears to be significant and requires an explanation. We can look for a solution of this issue in the conclusion of the fourth poem. This fact has not been adequately appreciated in the exegesis of the Lamentations. The expression Daughter of Zion appears for the last time in the final verse (w. 22a), in which the consummation of the punishment is proclaimed: "the punishment ... is accomplished." This proclamation is an important novelty, but it does not immediately become the object of hope. It has been mentioned already that it does not open a way back to the situation before the outbreak of the divine wrath. Such return is impossible, not only due to the complete destruction. In fact, it was the aim of this destruction, designed and meticulously executed by God, to prevent such return from occurring! As a result, there will be neither a possibility, nor even any need to use the title Daughter of Zion.

In the fifth poem, it is replaced with a simple "we": the voice of the deconstructed people of God. Now, in prayer, they depart from their glorious past through the tragic events (see vv. 2-18) and with some hope they await the unimaginable newness: חדש ימינו "renew our days" (v. 21 b), expressed through categories of distant past כקדם "as of old" (v. 21b). ${ }^{51}$ Clearly, as long as the people of God, Israel, the Daughter of Zion, connected their faith with the contempora-

49 Koenen (Klagelieder, $85^{*}$ ) notes that these twenty occurances constitue over a half of all the locations of these terms in the OT.

50 The existing abundant literature on this topic has recently been reviewed by Koenen (cf. Klagelieder, $84 *$ ) in the chapter "Die Verdichtung des Leids in Jerusalem als Person, Frau und Tochter," dedicated to a thorough investigation of this and other female figures in Lam.

51 See K. Koch, "Qädäm. Heilsgeschichte als mythische Urzeit im Alten (und Neuen) Testament," Spuren des hebräischen Denkens. Beiträge zur alttestamentlichen Theologie (ed. K. Koch) (Neukirchen-Vluyn: Neukirchere Verlaggesellschaft 1991) 259. 
neous form of state and the resulting form of social life intertwined with religious life, they were incapable of experiencing the new. Only the painful experience of the catastrophe opened first their eyes, and then their mouth, to plea to God, asking him for what is new. This turning towards the new, towards a new form of life not only individual, but also social, communal, constitutes the experience of repentance. Only such newness guarantees the authenticity of repentance. Any return to the old means walking back into the same paths and travelling the false ways, which have led them to a catastrophe.

This radical transformation of the people of God is announced in the figure of the geber. His questioned, depreciated identity does not result from his private defeat. Rather, it is a deep participation in the tragedy of the Daughter of Zion, of the people of God, which unfolds before his eyes. His participation in their fate is not limited to suffering or observing with empathy. It also encompasses the loss of the basis of his identity. Only in this way the geber, and the people of God can prepare themselves for change, for repentance without returning to the past. From the perspective of these two figures, and through them, in the whole of the Book of Lamentations, repentance is not a magical gift from God, but rather, his work, leading to the opening of our eyes to see the new. It comes through a dramatic history, which questions the old identity, even the one given by Him: that of the Daughter of Zion, or that of the geber.

\section{Translated by Elżbieta Lazarewicz-Wyrzykowska}

\section{Bibliography}

Albrektson, B., Studies in the Text and Theology of the Book of Lamentations with a Critical Edition of the Peshitta Text (Lund: Gleerup 1963).

Baumgartner, W. - Koehler, L., Hebrew and Aramaic Lexicon of the Old Testament (Leiden: Brill 1994-2000) I-II.

Berlin, A., Lamentations. A Commentary (Louisville, KY: Westminster John Knox 2002).

Bier, M.J., 'Perhaps there is Hope.' Reading Lamentations as a Polyphony of Pain, Penitence, and Protest (London: Bloomsbury 2015).

Boecker, H.J., Klagelieder (Zürcher Bibelkommentare. AT 21; Zürich: Theologischer Verlag 1985).

Conway, M.L., "Daughter Zion: Metaphor and Dialogue in the Book of Lamentations," Daughter

Zion. Her Portrait, Her Response (eds. M.J. Boda - C.J. Dempsey - L.S. Flesher) (Atlanta, GA:

Society of Biblical Literature 2012) 101-126.

Dobbs-Allsopp, F.W., Lamentations (Louisville, KY: John Knox Press 2002).

Emmendörffer, M., Der ferne Gott. Eine Untersuchung der alttestamentlichen Volksklagelieder vor dem Hintergrund der mesopotamischen Literatur (Tübingen: Mohr Siebeck 1998). 
Emmendörffer, M., Gottesnähe. Zur Rede von der Präsenz JHWHs in der Priesterschrift und verwandten Texten (Wissenschaftliche Monographien zum Alten und Neuen Testament 155; Göttingen: Vandenhoeck \& Ruprecht 2018).

Feldmeier, R. - Spieckermann, H., Der Gott der Lebendigen. Eine biblische Gotteslehre (Topoi Biblischer Theologie 1; Tübingen: Mohr Siebeck 2011).

Gottlieb, H., "Das kultische Leiden des Königs: Zu den Klageliedern 3,1," Scandinavian Journal of the Old Testament 1/2 (1987) 121-126.

Heim, K.M., "The Personification of Jerusalem and the Drama of Her Bereavement in Lamentations," Zion, City of our God (eds. R.S. Hess - G.J. Wenham) (Grand Rapids, MI: Eerdmans 1999) 129-170.

Joüon, P. - Muraoka, T., A Grammar of Biblical Hebrew (Subsidia biblica 14; Roma: PIB 1991) I-II.

Kang, Sh. - Venter, P.M., "A Canonical-Literary Reading Of Lamentations 5," Harvard Theological Studies 65/1 (2009) 1-7, DOI:10.4102/htsv65i1.278.

Koch, K., "Qädäm. Heilsgeschichte als mythische Urzeit im Alten (und Neuen) Testament," Spuren des hebräischen Denkens. Beiträge zur alttestamentlichen Theologie (ed. K. Koch) (Neukirchen-Vluyn: Neukirchere Verlaggesellschaft 1991) 248-280.

Koenen, K., Klagelieder (Threni) (Biblischer Kommentar. AT 20; Neukirchen-Vluyn: Neukirchere Verlaggesellschaft 2015).

Korzec, C., "I-the Strong Man in the Face of His Wrath (cf. Lam 3:1). A Man in Face of Divine Violence," Bible Caught in Violence (ed. C. Korzec) (New York - Berlin - London: Lang 2019) 75-89.

Kosmala, H., "gabhar", Theological Dictionary of the Old Testament (eds. G.J. Botterweck H. Ringgren) (Grand Rapids, MI: Eerdmans 1977) II, 367-382.

Kühlewein, J., "gbr," Theological Dictionary of the Old Testament (eds. G.J. Botterweck - H. Ringgren) (Grand Rapids, MI: Eerdmans 1974) I, 299-302.

Lanahan, W.F., "The Speaking Voice in the Book of Lamentations," Journal of Biblical Literature 93 (1974) 41-49.

Lee, N.C., "The Singers of Lamentations: (A)Scribing (De)Claiming Poets and Prophets," Lamentations in Ancient and Contemporary Cultural Contexts (eds. N. C. Lee - C. Mandolfo) (Atlanta, GA: Society of Biblical Literature 2008) 33-46.

Linafelt, T., Surviving Lamentations. Catastrophe, Lament, and Protest in the Afterlife of a Biblical Book (Chicago, IL: University of Chicago Press 2000).

Mandolfo, C., Daughter Zion Talks Back to the Prophet. A Dialogic Theology of the Book of Lamentations (Atlanta, GA: Society of Biblical Literature 2007).

Mandolfo, C., God in the Dock. Dialogic Tension in the Psalms of Lament (London: Sheffield Academic Press 2002).

Miller, C.W., Poetry and Personae. The Use and Functions of the Changing Speaking Voices in the Book of Lamentations (Diss. University of Denver; Denver, CO 1996).

Miller, C.W., "Reading Voices: Personification, Dialogism, and the Reader of Lamentations 1," Biblical Interpretation 9/4 (2001) 393-408.

Obara, E.M., Lamentazioni. Introduzione, traduzione e commento (Cinisello Balsamo: San Paolo 2012).

O'Connor, K.M., Lamentations and the Tears of the World (Maryknoll, NY: Orbis Books 2002). 
Pikor, W., "The Motif of God's Wrath in Zephaniah's Prophecy about the Day of Yahweh," The Biblical Annals 4/1 (2015) 41-55.

Provan, I., Lamentations. A Commentary, 2 ed. (Vancouver: Regent College Publishing 2016).

Ravasi, G., Il Libro dei Salmi. Commento e attualizzazione (Bologna: EDB 1993-1997) I-III.

Robinson, T.H., "Anacrusis in Hebrew Poetry," Werden und Wesen des Alten Testaments. Vorträge gehalten auf der Internationalen Tagung alttestamentlicher forscher zu Göttingen vom 4-10 September 1935 (eds. P. Volz - F. Stummer - J. Hempel) (Berlin: Töpelmann 1936) 37-40.

Saebø, M., "Who is 'the Man' in Lamentations 3? A Fresh Approach to the Interpretation of the Book of Lamentations," Understanding Poets and Prophets. Essays in Honour of George Wishart Anderson (ed. A.G. Auld) (Journal for the Study of the Old Testament Supplement Series 152; Sheffield: JSOT 1993) 294-306.

Salters, R.B., "The Unity of Lamentations" Irish Biblical Studies 23 (2001) 101-110.

Soltau, K.P., A Structural Analysis of the Book Lamentations (Diss. Bob Jones University; Greenville, SC 2003).

Thomas, H.A., "Feminist Interpretation(s) And Lamentations," Great Is Thy Faithfulness? Reading Lamentations as Sacred Scripture (eds. R.A. Parry - H.A. Thomas) (Eugene, OR: Pickwick 2011) $166-174$. 
